\title{
PERTUMBUHAN DAN HASIL HIJAUAN RUMPUT Eleusine indica (L) gaertn.) YANG DIPUPUK DENGAN JENIS DAN DOSIS BIOURIN BERBEDA
}

\author{
I Kadek Suradnyana, Ni Made Witariadi, dan I Wayan Wirawan \\ Program Studi Sarjana Peternakan, Fakultas Peternakan, Universitas Udayana, Denpasar, Bali \\ Email: kadeksuradnyana@student.unud.ac.id
}

\begin{abstract}
ABSTRAK
Penelitian bertujuan mengetahui pertumbuhan dan hasil hijauan rumput Eleusine indica (L) gaertn.) yang diberi pupuk biourin dengan jenis dan dosis berbeda, serta mengetahui interaksi antara jenis dan dosis biourin terhadap pertumbuhan dan hasil rumput E. Indica (L) gaertn.). Penelitian dilakukan di Farm Sesetan, Fakultas Peternakan, Universitas Udayana dan berlangsung selama 8 minggu. Percobaan menggunakan rancangan acak lengkap (RAL) pola faktorial dengan dua faktor yaitu faktor pertama, jenis biourin: biourin sapi (S) dan kambing (K) dan faktor kedua dosis biourin: o 1 ha $^{-1}$ (Do), 2.5001 ha $^{-1}$ (D1), 5.0oo 1 ha $^{-1}$ (D2), 7.500 $\mathrm{l} \mathrm{ha}^{-1}$ (D3) $10.000 \mathrm{l} \mathrm{ha} \mathrm{C}^{-1}$ (D4). Variabel yang diamati yaitu variabel pertumbuhan, hasil dan karakteristik tumbuh tanaman. Hasil penelitian menunjukkan bahwa tidak terjadi interaksi pada semua variabel pengamatan. Perbedaan jenis dan dosis pupuk biourin tidak berpengaruh terhadap pertumbuhan dan hasil rumput $E$. indica (L) gaertn.) kecuali pada variabel berat kering akar diperoleh tertinggi pada dosis $5.0001 \mathrm{ha}^{-1}$. Dapat disimpulkan bahwa pemberian pupuk biourin dengan jenis dan dosis berbeda tidak dapat memberikan pertumbuhan dan hasil hijauan E. indica (L) gaertn.) yang berbeda.
\end{abstract}

Kata kunci: biourin, dosis, hasil, Eleusin indica, pertumbuhan

\section{GROWTH AND YIELD OF ELEUSINE INDICA (L) GAERTN. GRASS FERTILIZED WITH DIFFERENT TYPES AND DOSAGE OF BIOURINE}

\begin{abstract}
This study aims to determine the growth and production of grass Eleusine indica (L) gaertn.) which was fertilized with different types and dosages of biourin, as well as to determine the interaction between the type and dosage of biourin on the growth and production of grass E. Indica (L) gaertn.). This study was conducted at Farm Sesetan, Faculty of Animal Science, Udayana University within 8 weeks. The experiment used a completely randomized design (CRD) factorial pattern with two factors, namely the first factor was the type of biourin which included cow $(\mathrm{S})$ and goat $(\mathrm{K})$ biourin and the second factor was the dosage of biourine: o $1 \mathrm{ha}^{-1}$ (Do), 2,500 $1 \mathrm{ha}^{-1}$ (D1) 5,000 l ha'-1 (D2), 7,500 $1 \mathrm{ha}^{-1}$ (D3) 10,000 l ha-1 (D4). The variables observed were growth, production, and plant growth characteristics. The results showed that there was no interaction between all the observed variables. The different types and dosages of biourin showed insignificantly different results on the growth and production of grass $E$. indica (L) gaertn.), unless in the variable of dry weight of the root which resulted the highest at 5,000 $1 \mathrm{ha}^{-1}$ dosage. Therefore, based on the results of the study, it can be concluded that there was no interaction between the type and dosage of biourin on the growth and production of the $E$. indica (L) gaertn.) grass.
\end{abstract}

Key words: biourine, dosage, Eleusin indica, growth, production

\section{PENDAHULUAN}

Penyediaan makanan ternak yang cukup sepanjang tahun baik kuantitas maupun kualitas merupakan salah satu upaya untuk menjaga kelangsungan produksi dan peningkatan produktivitas ternak. Menurut Tillman et al. (1983), pakan ternak merupakan segala sesuatu yang dapat dimakan atau dicerna oleh ternak tanpa mengganggu kesehatan ternak itu sendiri. Jenis pakan yang umum digunakan oleh peternak adalah hijauan. Menurut Susetyo (1980), hijauan pakan mempunyai peranan penting bagi ternak ruminansia dan merupakan pakan utama sebagai sumber gizi yaitu protein, energi, vitamin dan mineral.

Hambali (2015) menyatakan bahwa rumput belulang dapat tumbuh pada semua tempat dan dapat menimbulkan gangguan pada tanaman di sekitarnya. Rumput belulang memiliki kelebihan yaitu mampu 
berkembangbiak dengan cepat dan tumbuh liar pada area pertanian dan pekarangan rumah. Kelebihan lain dari rumput belulang yaitu akar rumput belulang mengandung senyawa golongan saponin, tanin, alkaloida dan golongan sterol atau terpen (Budhie, 2010). Rumput belulang memiliki juga kekurangan yaitu produksi dan pertumbuhannya rendah, sehingga produksi pertumbuhannya harus dipacu dengan menambahkan nutrisi melalui pemupukan, salah satu pupuk yang dapat digunakan yaitu limbah ternak seperti biourin sapi dan biourin kambing.

Biourin merupakan zat perangsang tumbuh yang dapat digunakan sebagai pengatur tumbuh yang dinyatakan oleh Aisyah et al. (2011). Biourin memberikan pengaruh positif terhadap pertumbuhan vegetatif tanaman. Menurut Lingga (2007) dalam Yuliarta (2014), jenis kandungan hara pada biourin yaitu 1,00\% N; 0,50\% P dan 1,50\% K. Hasil analisis di laboratorium menunjukkan kadar hara $\mathrm{N}, \mathrm{K}$ dan C-organik pada biourin yang difermentasi lebih tinggi dibanding urin atau cairan feses yang belum difermentasi. Kandungan nitrogen pada biourin meningkat dari rata-rata $0,34 \%$ menjadi $0,89 \%$, (Londra, 2008). Biourin yang dihasilkan hewan ternak sebagai hasil metabolisme tubuh memiliki nilai yang sangat bermanfaat yaitu kadar nitrogen dan kalium sangat tinggi, selain itu urin mudah diserap tanaman serta mengandung hormon pertumbuhan tanaman (Budhie, 2010)

Hasil penelitian Aisyah et al. (2011) menunjukkan bahwa pupuk urin sapi mengandung hormon tertentu yang dapat merangsang perkembangan tanaman dan mengandung lebih banyak $\mathrm{N}$ dan $\mathrm{K}$. Cekaman cuaca dan serangan hama dan penyakit serta meningkatkan pembentukan bunga dan bakal buah (Guntoro, 2006). Adijaya (2007) menyatakan bahwa pemberian urin sapi dengan dosis 7.500 liter/ha mampu meningkatkan biomassa rumput raja sebesar 90,18\% dibanding tanpa pemupukan dan berbeda tidak nyata pada pengamatan biomassa rumput raja yang diberi urea sebanyak $250 \mathrm{~kg} / \mathrm{ha}$. Menurut Witariadi et al. (2019) bahwa biourin memberikan manfaat untuk memperbaiki struktur fisik tanah, sehingga tanah menjadi lebih gembur, meningkatkan kemampuan tanah mengikat atau menahan air lebih lama yang bermanfaat saat musim kemarau, meningkatkan kesuburan tanah dan meningkatkan aktivitas cacing dan mikroorganisme tanah yang bermanfaat untuk tanah dan tanaman.

Berdasarkan uraian di atas maka perlu dilakukan penelitian pengaruh pemberian jenis dengan dosis biourin berbeda terhadap pertumbuhan dan hasil hijauan $E$. indica (L) gaertn.).

\section{MATERI DAN METODE}

Percobaan dilaksanakan di Rumah Kaca, Stasiun Penelitian Sesetan, Fakultas Peternakan, Universitas Udayana. Bibit yang digunakan adalah bibit rumput belulang (Eleusine indica) diperoleh dari Rumah Kaca, Stasiun Penelitian Sesetan, Fakultas Peternakan, Universitas Udayana. Bibit yang digunakan berupa anakan dari rumput belulang. Tanah yang digunakan berasal dari rumah kaca Farm Sesetan, Fakultas Peternakan Universitas Udayana. yang memiliki tekstur pasir berlempung dengan kandungan C organik $0,85 \%$ (sangat rendah), $\mathrm{N}$ total $0,04 \%$ (sangat rendah), $\mathrm{P}$ tersedia 106,02 ppm (sangat tinggi), kadar air kering udara $(\mathrm{Ku})$ 8,75\% dan kapasitas lapang $37,48 \%$. Tanah yang dipakai terlebih dahulu dikering udarakan, kemudian ditumbuk halus, selanjutnya diayak dengan tujuan agar ukuran partikel tanah merata. Tanah ditimbang dan dimasukkan ke dalam pot yang masing-masing diisi sebanyak $4 \mathrm{~kg}$ tanah kering udara. Tanah dalam pot kemudian disiram dengan air sampai kapasitas lapang.

Percobaan menggunakan pot yang berbahan dasar plastik yang berdiameter atas $28 \mathrm{~cm}$, diameter bawah $18 \mathrm{~cm}$ dan tinggi $20 \mathrm{~cm}$ sebanyak 30 buah. Pupuk yang digunakan dalam penelitian ini adalah biourin kambing dan biourin sapi yang diambil langsung dari peternakan kambing dan peternakan sapi yang ada di Desa Poh Santen, Kecamatan Mendoyo, Jembrana dan analisa dilakukan di Laboratorium Ilmu Tanah Fakultas Pertanian Universitas Udayana Bali.

Rancangan yang digunakan dalam penelitian ini yaitu rancangan acak lengkap (RAL). Perlakuan yang diberikan adalah dosis biourin kambing dan biourin sapi yang terdiri atas : o $1 \mathrm{ha}^{-1}$ (Do), $2.500 \mathrm{l} \mathrm{ha}^{-1}$ (D1): $5.0001 \mathrm{ha}^{-1}$ (D2): $7.5001 \mathrm{ha}^{-1}$ (D3): 10.000 $1 \mathrm{ha}^{-1}$ (D4). Setiap perlakuan diulang sebanyak tiga kali sehingga terdapat 30 pot percobaan. Variabel yang diamati dalam penelitian ini: tinggi tanaman, jumlah daun, jumlah anakan, lingkar rumpun berat kering daun, berat kering batang, berat kering akar, berat kering total hijauan, nisbah berat kering daun dengan berat kering batang, nisbah berat kering total hijauan dengan berat kering akar, dan luas daun per pot $\left(\mathrm{cm}^{2}\right)$.

Hasil Analisis Biourin Sapi dan Biourin Kambing

\begin{tabular}{|c|c|c|c|}
\hline Parameter & Satuan & Biourin Sapi & Biourin Kambing \\
\hline Nilai pH (1:2.5) & $\mathrm{H}_{2} \mathrm{O}$ & 8,1 & 7,1 \\
\hline DHL & $\mathrm{mmmhos} / \mathrm{cm}$ & 10,70 & 45,30 \\
\hline $\mathrm{C}$ - Organik & $\%$ & 0,78 & 6,23 \\
\hline N Total & $\%$ & 0,01 & 0,37 \\
\hline P Tersedia & ppm & 44,74 & 48,21 \\
\hline K Tersedia & ppm & 261,00 & 252,00 \\
\hline
\end{tabular}

Sumber : Laboratorium Ilmu Tanah Fakultas Pertanian Universitas Udayana Bal Tahun 2020

Singkatan: $\mathrm{C}=$ Karbon, $\mathrm{N}=$ Nitrogen, $\mathrm{P}=$ Posfor, $\mathrm{K}=$ Kalium 


\section{HASIL DAN PEMBAHASAN}

Pertumbuhan rumput belulang pada perlakuan jenis dan dosis biourin, menunjukkan hasil berbeda tidak nyata $(\mathrm{P}>0,05)$ pada semua variabel pertumbuhan (tinggi tanaman, jumlah daun, jumlah anakan dan lingkar rumpun) (Tabel 1). Hasil penelitian menunjukkan bahwa pemberian jenis pupuk biourin sapi dan kambing pada rumput $E$. indica (L) gaertn.) menunjukkan hasil pertumbuhan yang sama. Hal ini karena $\mathrm{C} / \mathrm{N}$ ratio pada biourin sapi sangat tinggi yaitu 78 , tetapi $\mathrm{C} / \mathrm{N}$ ratio pada biourin kambing rendah yaitu 16,84. C/N ratio yang tinggi akan terjadi proses dekomposisi lambat dan $\mathrm{C} / \mathrm{N}$ ratio yang rendah akan mengakibatkan $\mathrm{N}$ basa kurang akibat teroksidasi, sehingga pertumbuhan rumput belulang menjadi sama. Hidayati et al. (2011) menambahkan semakin tinggi nitrogen yang tersedia di tanah, maka multiplikasi mikroorganisme yang merombak fosfor semakin meningkat, sehingga kandungan fosfor juga meningkat. Dimana mikroorganisme memiliki fase stasioner yaitu fase pertumbuhan yang berpengaruh terhadap peningkatan kandungan posfor. Poerwowidodo (1992) dan Sutedjo (2002) menyatakan nitrogen diperlukan untuk merangsang pertumbuhan vegetatif, memperbesar ukuran daun dan meningkatkan kandungan klorofil. Peningkatan klorofil pada daun akan mempercepat proses fotosintesis.

Pemberian dosis 2.500 1 ha $^{-1}$ (D1) menunjukan hasil nyata tertinggi pada variabel tinggi tanaman, jumlah daun, jumlah anakan dan lingkar rumpun masing-masing sebesar 56,05 cm, 49,67 helai,7,34 anakan dan 16,40 cm (Tabel 1). Namun seiring dengan peningkatan level pemberian biourin terjadi penurunan pada variabel pertumbuhan rumput, hal ini diduga karena rumput belulang merupakan jenis rumput lokal yang kurang responsif terhadap pemupukan, sehingga apabila dosis pupuk biourin ditingkatkan maka pertumbuhannya sama. Nengsih (2013) menyatakan bahwa rumput belulang merupakan tanaman liar yang habitat hidupnya jarang dipengaruhi bahan kimia, sehingga rumput belulang kurang responsif terhadap pemupukan. Hasil berbeda didapatkan dalam penelitian Mertaningsih et al. (2019), semakin banyak pemberian biourin sapi pada rumput Axonopus compressus, Stenotaphrum secundatum, dan Paspalum conjugatum, maka semakin tinggi pertumbuhan pada tanaman, namun secara statistik juga berbeda tidak nyata $(\mathrm{P}>0,05)$.

Pemberian jenis pupuk biourin sapi dan kambing pada rumput $E$. indica (L) gaertn.) menunjukkan hasil yang sama. Hal ini disebabkan pemberian jenis biourin menghasilkan pertumbuhan yang sama juga, sehingga hasil rumput belulang seperti berat kering daum, batang, akar dan total hijauan juga sama. Husma (2010) menyatakan pemberian bahan organik (pupuk kandang) berpengaruh terhadap pertumbuhan tanaman seperti peningkatan kegiatan respirasi, bertambah lebarnya daun yang berpengaruhterhadap kegiatan fotosintesis yang bermuara pada produksi dan kandungan bahan kering.

Hasil penelitian rumput E. indica (L) gaertn.) menunjukkan bahwa perlakuan pemberian dosis 2 . $1 \mathrm{ha}^{-1}$ (D1) terhadap berat kering daun, berat kering batang dan berat kering total hijauan, menunjukkan perbedaan yang tidak nyata. Hal ini dikarenakan biourin sapi dan kambing mengandung $\mathrm{N}$ yang rendah, menyebabkan kurang tersedianya kandungan unsur hara pada tanaman. Wahyuni et al. (2018) menyatakan bahwa penambahan penggunaan pupuk organik lebih berperan dalam memperbaiki kesuburan

Tabel 1. Pertumbuhan Rumput Eleusine indica (L) gaertn.) yang Dipupuk dengan Jenis dan Dosis Biourin Berbeda

\begin{tabular}{|c|c|c|c|c|c|c|c|c|}
\hline \multirow{2}{*}{ Variabel } & \multirow{2}{*}{$\begin{array}{c}\text { Jenis Pupuk } \\
\text { Kandang }\end{array}$} & \multicolumn{4}{|c|}{ Dosis $^{2)}$} & \multirow[b]{2}{*}{ D4 } & \multirow{2}{*}{ Rataan } & \multirow{2}{*}{ SEM 3 ) } \\
\hline & & Do & D1 & D2 & D3 & & & \\
\hline \multirow{3}{*}{$\begin{array}{l}\text { Tinggi tana- } \\
\operatorname{man}(\mathrm{cm})\end{array}$} & BS & 47,93 & 55,73 & 52,67 & 52,77 & 49,03 & $51,63^{A}$ & \multirow[t]{3}{*}{4,12} \\
\hline & $\mathrm{BK}$ & 43,43 & 56,37 & 52,37 & 51,73 & 49,47 & $50,67^{\mathrm{A}}$ & \\
\hline & Rataan & $45,68^{a 4)}$ & $56,05^{\mathrm{a}}$ & $52,5^{2^{a}}$ & $52,25^{\mathrm{a}}$ & $49,25^{\mathrm{a}}$ & & \\
\hline \multirow{3}{*}{$\begin{array}{l}\text { Jumlah daun } \\
\text { (helai) }\end{array}$} & $\mathrm{BS}$ & 41,67 & 48,67 & 44,00 & 51,33 & 48,00 & $46,73^{\mathrm{A}}$ & \multirow[t]{3}{*}{5,06} \\
\hline & $\mathrm{BK}$ & 51,00 & 50,67 & 52,00 & 44,33 & 46,33 & $48,87^{\mathrm{A}}$ & \\
\hline & Rataan & $46,34^{\mathrm{a}}$ & $49,67^{\mathrm{a}}$ & $48,00^{\mathrm{a}}$ & $47,83^{a}$ & $47,17^{\mathrm{a}}$ & & \\
\hline \multirow{3}{*}{$\begin{array}{c}\text { Jumlah } \\
\text { anakan } \\
\text { (anakan) }\end{array}$} & $\mathrm{BS}$ & 7,00 & 7,00 & 7,00 & 6,67 & 6,67 & $6,87^{\mathrm{A}}$ & \multirow[t]{3}{*}{0,55} \\
\hline & $\mathrm{BK}$ & 7,00 & 7,67 & 7,67 & 7,33 & 7,33 & $7,40^{\mathrm{A}}$ & \\
\hline & Rataan & $7,00^{a}$ & $7,34^{\mathrm{a}}$ & $7,34^{\mathrm{a}}$ & $7,00^{\mathrm{a}}$ & $7, \mathrm{OO}^{\mathrm{a}}$ & & \\
\hline \multirow{3}{*}{$\begin{array}{l}\text { Lingkar rum- } \\
\text { pun }(\mathrm{cm})\end{array}$} & $\mathrm{BS}$ & 11,23 & 17,87 & 15,00 & 19,50 & 9,97 & $14,71^{\mathrm{A}}$ & \multirow[t]{3}{*}{3,26} \\
\hline & $\mathrm{BK}$ & 12,27 & 14,93 & 17,73 & 11,27 & 15,03 & $14,25^{\mathrm{A}}$ & \\
\hline & Rataan & $11,75^{\mathrm{a}}$ & $16,40^{\mathrm{a}}$ & $16,37^{\mathrm{a}}$ & $15,39^{\mathrm{a}}$ & $12,5 \mathrm{O}^{\mathrm{a}}$ & & \\
\hline
\end{tabular}

Keterangan:

1) $\mathrm{BS}=$ Biourin sapi, $\mathrm{BK}=$ Biourin kambing.

2) $\mathrm{D} 0=0 \mid$ ha-1, $\mathrm{D} 1=2.500 \mid$ ha-1, $\mathrm{D} 2=5000 \mid$ ha-1, $\mathrm{D} 3=7.500 \mid$ ha- $1, \mathrm{D} 4=10.000 \mid$ ha- 1

3) $\mathrm{SEM}=$ Standard Error of theTreatment Means

4) Nilai dengan huruf kapital sama pada kolom yang sama dan huruf kecil yang sama pada baris yang sama menunjukkan berbeda tidak nyata $(P>0,05)$ 
Tabel 2. Hasil Rumput Eleusine indica (L) gaertn.) yang Dipupuk dengan Jenis dan Dosis Biourin Berbeda

\begin{tabular}{|c|c|c|c|c|c|c|c|c|}
\hline \multirow{2}{*}{ Variabel } & \multirow{2}{*}{$\begin{array}{c}\text { Jenis Pupuk } \\
\text { Kandang1) }\end{array}$} & \multicolumn{5}{|c|}{ Dosis $^{2)}$} & \multirow{2}{*}{ Rataan } & \multirow{2}{*}{ SEM $^{3)}$} \\
\hline & & Do & D1 & D2 & D3 & D4 & & \\
\hline \multirow{3}{*}{$\begin{array}{l}\text { Berat Kering } \\
\text { Daun }(\mathrm{g})\end{array}$} & BS & 1,87 & 3,20 & 2,73 & 2,57 & 2,20 & $2,51^{\mathrm{A}}$ & \multirow[t]{3}{*}{0,36} \\
\hline & $\mathrm{BK}$ & 2,40 & 2,43 & 2,43 & 2,23 & 2,40 & $2,38^{\mathrm{A}}$ & \\
\hline & Rataan & $2,14^{\mathrm{a} 4)}$ & $2,82^{a}$ & $2,58^{\mathrm{a}}$ & $2,40^{\mathrm{a}}$ & $2,30^{\mathrm{a}}$ & & \\
\hline \multirow{3}{*}{$\begin{array}{c}\text { Berat Kering } \\
\text { Batang (g) }\end{array}$} & BS & 6,53 & 7,13 & 4,37 & 6,43 & 4,90 & $5,87^{\mathrm{A}}$ & \multirow[t]{3}{*}{1,08} \\
\hline & $\mathrm{BK}$ & 4,77 & 6,60 & 5,93 & 3,90 & 4,50 & $5,14^{\mathrm{A}}$ & \\
\hline & Rataan & $5,65^{\mathrm{a}}$ & $6,87^{\mathrm{a}}$ & $5,15^{\mathrm{a}}$ & $5,17^{\mathrm{a}}$ & $4,70^{\mathrm{a}}$ & & \\
\hline \multirow{3}{*}{$\begin{array}{l}\text { Berat Kering } \\
\quad \text { Akar }(g)\end{array}$} & BS & 0,50 & 2,73 & 1,43 & 1,50 & 1,10 & $1,45^{\mathrm{A}}$ & \multirow[t]{3}{*}{0,37} \\
\hline & BK & 1,33 & 1,97 & 1,93 & 0,77 & 1,00 & $1,40^{\mathrm{A}}$ & \\
\hline & Rataan & $0,92^{\mathrm{b}}$ & $2,35^{\mathrm{a}}$ & $1,68^{\mathrm{ab}}$ & $1,14^{\mathrm{b}}$ & $1,05^{\mathrm{b}}$ & & \\
\hline \multirow{3}{*}{$\begin{array}{l}\text { Berat Kering } \\
\text { Total Hijauan } \\
\quad(\mathrm{g})\end{array}$} & BS & 8,40 & 10,33 & 7,10 & 9,00 & 7,10 & $8,39^{\mathrm{A}}$ & \multirow[t]{3}{*}{1,01} \\
\hline & $\mathrm{BK}$ & 7,17 & 9,03 & 8,37 & 6,13 & 6,90 & $7,52^{\mathrm{A}}$ & \\
\hline & Rataan & $7,79^{\mathrm{a}}$ & $9,68^{\mathrm{a}}$ & $7,74^{\mathrm{a}}$ & $7,57^{\mathrm{a}}$ & $7,0^{\mathrm{a}}$ & & \\
\hline
\end{tabular}

Keterangan:

1) $\mathrm{BS}=$ Biourin sapi, $\mathrm{BK}=$ Biourin kambing

2) $\mathrm{D} 0=0 \mathrm{I}$ ha-1, D1 $=2.500 \mathrm{I}$ ha-1, D2 $=5000 \mathrm{I}$ ha-1, D3 $=7.500 \mathrm{I}$ ha- $-1, \mathrm{D} 4=10.000 \mathrm{I}$ ha- 1

3) $\mathrm{SEM}=$ Standard Error of theTreatment Means

4) Nilai dengan huruf kapital sama pada kolom yang sama dan huruf kecil yang sama pada baris yang sama menunjukkan berbeda tidak nyata $(P>0,05)$

tanah dan kualitas tanaman dibandingkan sebagai penyedia unsur hara. Pupuk organik harus mengalami proses dekomposisi dan mineralisasi terlebih dahulu, kemudian menghasilkan unsur $\mathrm{N}$ yang dibutuhkan oleh tanaman (Ramadhani et al., 2016).

Berat kering akar pada perlakuan D1 menujukkan hasil peningkatan yang signifikan sebesar 2,35 g dan lebih tinggi dari perlakuan lainnya. Hal ini karena kandungan C-organik yang ada pada biourin yang membantu menyuburkan tanah, sehingga biomassa akar menjadi lebih tinggi. Herdiyanti (2017) menyatakan bahwa berat kering akar erat kaitanya dengan biomassa akar, maka semakin tinggi biomassa akar maka berat kering akar semakin berat. Menambahkan C-organik tanah yang tinggi dapat membantu keberlanjutan kesuburan tanah, melindungi kualitas tanah dan air yang terkait dalam siklus hara, air, dan biologi. Chanan (2012) menambahkan setiap penambahan kandungan biomassa akan diikuti oleh penambahan kandungan stok karbon, hal ini menjelaskan bahwa karbon dan biomassa memiliki hubungan yang positif. Hasil penelitian ini berbeda dengan hasil penelitian Widana et al. (2015) berupa pemberian dosis pupuk organik sapi, sapi+ayam, dan kambing+sapi pada rumput benggala menghasilkan berat kering daun, berat kering batang, dan berat kering tajuk yang nyata lebih tinggi dari tanpa pemberian pupuk organik dan menghasilkan berat akar yang tidak berbeda nyata antara perlakuan pemberian dosis pupuk organik.

Hasil rumput belulang yang diberi perlakuan dosis pupuk biourin, menunjukkan hasil berbeda tidak nyata $(\mathrm{P}>0,05)$ pada semua variabel karakteristik tumbuh tanaman (Tabel 3). Pemberian jenis pupuk biourin sapi dan kambing pada rumput $E$. indica (L) gaertn.) menunjukkan hasil nisbah berat kering daun dengan berat kering batang dan nisbah berat kering total hijauan dengan berat kering akar yang sama. Ini disebabkan karena respon tanaman menghasilkan berat kering daun, batang, akar dan total hijauan yang sama juga. Hasil penelitian ini sejalan dengan hasil penelitian Widana et al. (2015) berupa pemberian jenis pupuk organik sapi, sapi+ayam, dan kambing+sapi pada rumput benggala tidak berpengaruh terhadap nisbah berat kering daun dengan berat kering batang dan nisbah berat kering tajuk dengan berat kering akar, disebabkan oleh ketiga jenis pupuk organik menghasilkan hijauan dengan kualitas yang sama.

Pemberian biourin sapi secara nyata meningkatkan luas daun rumput belulang sebesar 23,59\% dibandingkan biourin kambing. Hal ini disebabkan biourin sapi mengandung magnesium $(\mathrm{Mg})$ dan kalium (K) yang lebih tinggi dari biourin kambing. Menurut Mertaningsih et al. (2019) biourin sapi mengandung unsur magnesium $(\mathrm{Mg}$ ) yang berfungsi sebagai penyusun klorofil sehingga unsur ini berberan penting terhadap pertumbuhan daun. Lakitan (2000) menambahkan unsur Mg berfungsi sebagai penyusun klorofil sehingga mampu meningkatkan laju fotosintesis. Sementara kalium dapat berperan dalam memacu penyerapan air sebagai akibat hadirnya ion $\mathrm{K}^{+}$, sehinggga akan dapat memacu meningkatnya tekanan turgor sel yang mengakibatkan proses membuka dan menutupnya stomata (Marschner, 2012). Membukanya stomata tersebut, akan memacu berlangsungnya proses asimilasi tanaman yang pada akhirnya akan berdampak pada banyaknya asimilat yang dihasilkan (Apriliani et al., 2016). Asimilat merupakan energi yang digunakan untuk pertumbuhan, walaupun sebagian dari energi tersebut juga akan disimpan sebagai cadangan makanan yang akan disimpan dalam organ penyimpanan (Susanto et al., 2014). Hasil penelitian ini sejalan dengan hasil penelitian Wahyuni et al. (2018), rataan luas daun 
Tabel 3. Karakteristik Tumbuh Rumput E. Indica (L) gaertn.) yang Dipupuk dengan Jenis dan Dosis Biourin Berbeda

\begin{tabular}{|c|c|c|c|c|c|c|c|c|}
\hline \multirow{2}{*}{ Variabel } & \multirow{2}{*}{$\begin{array}{c}\text { Jenis Pupuk } \\
\text { Kandang1) }\end{array}$} & \multicolumn{5}{|c|}{ Dosis ${ }^{2)}$} & \multirow{2}{*}{ Rataan } & \multirow{2}{*}{ SEM $\left.^{3}\right)$} \\
\hline & & Do & D1 & D2 & D3 & D4 & & \\
\hline \multirow{3}{*}{$\begin{array}{l}\text { Nisbah berat kering daun dengan } \\
\text { berat kering batang }\end{array}$} & BS & 0,33 & 0,53 & 0,74 & 0,41 & 0,50 & $0,50^{A}$ & 0,18 \\
\hline & $\mathrm{BK}$ & 0,66 & 0,37 & 0,51 & 0,62 & 0,54 & $0,54^{\mathrm{A}}$ & \\
\hline & Rataan & $0,5 \mathrm{O}^{\mathrm{a} 4)}$ & $0,45^{\mathrm{a}}$ & $0,63^{\mathrm{a}}$ & $0,52^{\mathrm{a}}$ & $0,52^{\mathrm{a}}$ & & \\
\hline \multirow{3}{*}{$\begin{array}{l}\text { Nisbah berat kering total hijauan } \\
\text { dengan berat kering akar }\end{array}$} & BS & 0,07 & 0,28 & 0,21 & 0,17 & 0,16 & $0,18^{A}$ & 0,06 \\
\hline & $\mathrm{BK}$ & 0,22 & 0,20 & 0,24 & 0,12 & 0,15 & $0,19^{\mathrm{A}}$ & \\
\hline & Rataan & $0,15^{\mathrm{a}}$ & $0,24^{\mathrm{a}}$ & $0,23^{a}$ & $0,15^{\mathrm{a}}$ & $0,16^{a}$ & & \\
\hline \multirow{3}{*}{$\begin{array}{c}\text { Luas daun } \\
\text { per pot }\left(\mathrm{cm}^{2}\right)\end{array}$} & BS & $4.699,61$ & $5.679,41$ & $4 \cdot 758,98$ & $3 \cdot 477,37$ & $3.469,78$ & $4.417,03^{\mathrm{A}}$ & 725,82 \\
\hline & BK & $3.145,16$ & $3.479,19$ & $3 \cdot 947,11$ & $3 \cdot 384,61$ & $2.919,98$ & $3 \cdot 375,21^{\mathrm{B}}$ & \\
\hline & Rataan & $3 \cdot 922,39^{\mathrm{a}}$ & $4 \cdot 579,30^{\mathrm{a}}$ & $4.353,06^{\mathrm{a}}$ & $3 \cdot 430,99^{\mathrm{a}}$ & $3.194,88^{\mathrm{a}}$ & & \\
\hline
\end{tabular}

Keterangan:

1) $\mathrm{BS}=$ Biourin sapi, $\mathrm{BK}=$ Biourin kambing.

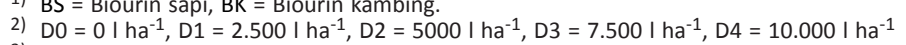

3) $\mathrm{SEM}=$ Standard Error of theTreatment Means

4) Nilai dengan huruf kapital sama pada kolom yang sama dan huruf kecil yang sama pada baris yang sama menunjukkan berbeda tidak nyata ( $P>0,05$ )

per pot berbeda nyata $(\mathrm{P}<0,05)$ antar perlakuan kombinasi hal ini terkait dengan jumlah daun sehingga memperluas helai daun dan meningkatkan proses fotosintesis.

Dosis pupuk organik tidak berpengaruh terhadap nisbah berat kering daun dengan berat kering batang dan nisbah berat kering total hijauan dengan berat kering akar serta luas daun rumput. Hal ini mengindikasikan bahwa pemberian dosis pupuk organik menghasilkan hijauan dengan kualitas yang sama. Widana et al. (2015) menambahkan dihasilkannya hijauan dengan kualitas yang sama disebabkan oleh peningkatan berat kering daun diikuti oleh peningkatan berat kering batang, begitu juga dengan meningkatnya berat kering total hijauan diikuti oleh peningkatan berat kering akar. Wahyuni et al. (2018) menambahkan nisbah berat kering total hijauan dengan berat kering akar berbeda tidak nyata disebabkan karena daya serap tanaman terhadap unsur hara relatif sama sehingga penambahan pupuk nitrogen dengan dosis yang beragam tidak menunjukkan hasil yang berbeda nyata.

\section{SIMPULAN}

hasil penelitian ini dapat disimpulkan bahwa pemberian jenis dan dosis biourin berbeda menghasilkan pertumbuhan dan hasil hijauan yang sama pada rumput $E$. indica (L) gaertn.), jenis biourin sapi mampu meningkatkan luas daun per pot dan pemberian dosis $2.500 \mathrm{l} /$ ha mampu meningkatkan berat kering akar pada rumput $E$. indica (L) gaertn.).

\section{DAFTAR PUSTAKA}

Aisyah, S., N. Sunarlim, B. Solfan. 2011. Pengaruh urine sapi terfermentasi dengan dosis dan interval pemberian yang berbeda terhadap pertumbuhan tanaman sawi (Brassica juncea
L.). Jurnal Agroteknologi. 2(1): 1-5.

Apriliani, I. N., S. Heddy, dan N. E. Suminarti. 2016. Pengaruh kalium pada pertumbuhan dan hasil dua varietas tanaman ubi jalar (Ipomea batatas (L.) Lamb). Jurnal Produksi Tanaman Vol. 4 (4): 264-270.

Budhie, D. D. S. 2010. Aplikasi Urin Kambing Peranakan Etawa dan Nasa Sebagai Pupuk Organik Cair untuk Pemacu Pertumbuhan dan Produksi Tanaman Pakan Legum Indigofera sp. Skripsi. Sarjana Peternakan, Fakultas Peternakan, institut Pertanian Bogor Bogor,

Lakitan, B. 2000. Dasar-Dasar Fisiologi Tumbuhan. PT. Raja Grafindo Persada. Jakarta.

Marschner, P. 2012. Mineral Nutrition of Higher Plants Third Edition. Elsevier Ltd. Oxford.

Mertaningsih, N. P. L., N. N. Suryani, dan M. A. P. Duarsa. 2019. Pertumbuhan dan produksi rumput Axonopus compressus, Stenotaphrum secundatum, dan Paspalum conjugatum pada berbagai level biourin. Jurnal Peternakan Tropika Vol. 7 (1): 864-88o. https://ojs.unud.ac.id/index. php/tropika/article/view/52333/30945/ Diakses tanggal 25 agustus 2020

Nengsih, W. P. 2013. Isolasi actinomycetes dari rizosfer rumput belulang(Eleusine indica (1.) gaertn.) sebagai penghasil antibiotik. Naskah Publikasi Fakultas Farmasi Universitas Muhammadiyah Surakarta.

Poerwowidodo. 1992. Telaah Kesuburan Tanah. Penerbit Angkasa. Bandung.

Ramadhani, R. H., M. Roviq dan M. D. Maghfoer. 2016.Pengaruh sumber pupuk nitrogen dan waktu pemberian urea pada pertumbuhan dan hasil tanaman jagung manis (Zea mays Sturt. var. saccharata). Jurnal Produksi Tanaman. 4 (1); 8-15.

Wahyuni, S. S., I K. M. Budiasa, dan I W. Suarna. 2018. Substitusi pupuk urea dengan pupuk 
bio-slurry sapi terhadap pertumbuhan dan produksi rumput Stenotaphrum secundatum. Jurnal Peternakan Tropika Vol. 6 (2): 283-297. https://ojs.unud.ac.id/index.php/tropika/ article/view/40274/24474/. Diakses tanggal 18 septeber 2020

Steel R. D. G., dan Torrie J. H. 1991. Prinsip dan Prosedur Statistika. Penerbit PT. Gramedia. Jakarta.

Susanto, E., N. Herlina dan N. E. Suminarti. 2014. Respon pertumbuhan dan hasil tanaman ubi jalar (Ipomoea batatas L.) pada beberapa macam dan waktu aplikasi bahan organik. Jurnal Produksi Tanaman. 2 (5): 412-418.

Susetyo. S., I. Kismono, dan B. Soewandi. 1980. Hijauan Makanan Ternak. Direktorat Jenderal Peternakan. Departemen Pertanian. Jakarta

Widana, G. A. A., N. G. K. Roni, dan A. A. A. S. Trisnadewi. 2015. Pertumbuhan dan produksi rumput benggala (Panicum maximum $c v$ Trichoglume) pada berbagai jenis dan dosis pupuk organik. Jurnal Peternakan Tropika Vol. 3 (2): 405-417. https://ojs.unud.ac.id/index.php/ tropika/article/view/18601/12069/ Diakses 07 dec. 2020.

Witariadi, N. M., dan N. C. Kusumawati. 2019. Efek substitusi pupuk urea dengan pupuk bio slurry terhadap produktivitas rumput benggala (Panicum maximum $\mathrm{cv}$ Trichoglume). Pastura Vol. 8 (2): 86-91. https://ojs.unud.ac.id/ index.php/pastura/article/view/54837/32468/ Diakses 07 dec. 2020.

Yuliarta, B. 2014. Pengaruh biourine sapi dan berbagai dosis pupuk NPK terhadap pertumbuhan dan hasil tanaman selada krop (Lactuca Sativa L). J. Produksi Tanaman 1(6): 522-531.

Hidayati, Y. A., T. B. Benito A. Kurnani, Eulis T. Marlina dan E. Harlia. 2011. Kualitas pupuk cair hasil pengolahan feses sapi potong menggunakan Saccharomyces cereviceae. Jurnal Ilmu Ternak, Vol. 11(2): $104-107$. 